\title{
PROFIL LEMBAGA PEMASYARAKATAN MAROS (SEBUAH KASUS EVALUATIF TERHADAP PELAKSANAAN PEMBINAAN NARAPIDANA)
}

\author{
Oleh : H. Abdul Kadir Ahmad
}

\section{PENDAHULUAN}

A. Latar Belakang Masalah

Lembaga Pemasyarakatan adalah institusi sosial yang sudah berusia tua. Keberadaannya seiring dengan terbentuknya dan berkembangnya masyarakat. Oleh karena itu, eksistensi lembaga ini sangat tergantung kepada perkembangan masyarakat. Semakin berkembang suatu masyarakat, akan semakin rumit pula bentuk lembaga pemasyarakatan.

Pada suatu mas a tertentu, pengertian Lembaga Pemasyarakatan lebih dikenal sebagai tempat menjalani hukuman bagi orang-orang yang telah melanggar peraturan negara. Pengertian ini pada gilirannya telah melahirkan pemahaman bahwa fungsi tunggal lembagan pemasyarakatan adalah sebagai tempat hukuman bagi orangorang yang melanggar hukum. Akibatnya narapidana selalu dipandang sebagai orang bersalah dan jahat.

Pemerintah Indonesia sejak dekade akhir ini melalui Departemen Kehakiman cq Direktorat Jenderal Pemasyarakatan, LP tidak lagi dikesankan sebagai tempat yang angker dan menakutkan, yang akan membuat jera dan takut, tetapi mulai diorientasikan menjadi satu tempat khusus mempersiapkan Napi kembali dan diterima oleh masyarakat. Untuk itu, di- samping pemberian pengetahuan dan keterampilan praktis, mulai ditingkatkan pula kegiatan pembinaan mental dan spiritual, pembinaan wawasan kebangsaan, kemasya.rakatan, dan bimbingan keagamaan.

Meski demikian, sementara ini masyarakat luas belum mengetahui secarajelas bagaimana pola pembinaan tersebut dan apakah pembinaan dalam Lapas sungguh-sungguh telah mencerminkan citra baru dari Lembaga Pemasyarakatan ? Jika belum, faktor-faktor apakah yang merupakan kendala terlaksananya pola pembinaan tersebut ? Masalah itulah yang menjadi fokus perhatian penulis lewat penelitian ini dengan mengambil sampel di Lembaga Pemasyarakatan Kelas II Maros Sulawesi Selatan.

\section{B. Tujuan dan Kegunaan Penelitian}

1. Mengetahui praktek pembinaan narapidana di Lembaga Pemasyarakatan Kelas II Maros.

2. Melakukan identifikasi apakah pola pembinaan sebagaimana tertuang dalam Pedoman Pembinaan Napi terlaksana di lapangan ?

3. Mengenal kendala dan permasalahan yang dialami Lapas dalam melakukan pembinaan terhadap Napi.

Penelitian ini akan bermanfaat bagi masyarakat untuk mengetahui hal-hal 
yang berkaitan dengan citra Lembaga Pemasyarakatan. Bagi Departemen Kehakiman, dan Departemen terkait, penelitian ini.dapat menjadi masukan pengambilan kebijakan berkaitan dengan pembinaan narapidana di masa datang.

\section{Metodologi Penelitian}

1. Sifat penelitian

Penelitian ini menggunakan pendekatan kualitatif, dimana tekanan penelitian diarahkan kepada upaya melakukan identifikasi terhadap pelaksanaan pembinaan narapidana pada lembaga pemasyarakatan. Oleh karena itu bentuk penelitian ini bersifat deskriptif dan kasuistik.

2. Sasaran

Sasaran penelitian adalah Lembaga Pemasyaratan Kelas II Maros Sulawesi Selatan, berlangsung dari Juli-Desember 1994.

3. Teknik Pengumpulan Data

Teknik Pengumpulan data penelitian ini adalah :

\section{a. Wawancara mendalam}

Teknik ini digunakan untuk mengumpulkan data primer. Wawancara dilakukan dengan kepalakepala seksi/bagian yang terkait dengan pembinaan Napi, dan dengan beberapa orang narapidana.

b. Pengamatan

Teknik ini digunakan untuk merekam lingkungan fisik, suasana lingkungan Lapas, prilaku petugas dan narapidana.

c. Teknik pencatatan

Teknik digunakan untuk merekam data-data sekunder, monografi berupa struktur lembaga, daftar kegiatan, grafik, dan data-data statistik.

4. Pengolahan dan Analisa Data

Pengolahan data dilakukan melalui proses klasifikasi dan kategorisasi data. Seluruh data yang terekam dikelompokkan menurut jenis dan sifatnya kemudian dimasukkan kedalam aspek-aspek masalah yang diperhatikan. Selanjutnya data tersebut dianalisa dengan menggunkan analisa deskriptif interpretatif.

\section{II \\ PROFIL LEMBAGA PEMA- SYARAKATAN MAROS}

A. Kondisi Fisik

Lembaga Pemasyartakatan Maros berlokasi dodusun Kandeapi Desa Bontoromba kecamatan Mandai, 3 $\mathrm{km}$ dari jalan raya poros Ujung pandang-Maros, atau $13 \mathrm{~km}$ dari ibukota Kabupaten Maros. Lembaga pemasyarakatan ini tergolong dalam kualifikasi Kelas II B, yaitu kualifikasi yang diberikan untuk Lapas berkapasitas daya muat dibawah 500 orang, selainpertimbangan beban kerja dan faktor lokasi. Status itu ditetapkan lewat Keputusan Menteri Kehakiman Nomor M.01.PR.07.10 tahun 1985. lapas yang terletak dijalan raya Kariango ini terbilang baru. Meski pembagian fisiknya mulai dikerjakan tahun anggaran 1981/1982, penggunaanna baru pada tanggal 18 Agustus 1988. Sebelumnya, Lapas Maros berlokasi di jalan Lanto Daeng Pasewang, kota Maros. Sejarah Lapas Maros dimulai sejak tahun 1944 dengan status penjara.Pada tahun 1964 statusnya berubah menjadi Lembaga Pemasyarakatan.

Lapas Maros menempati bangunan

No. 12 Th. VII Juli/Desember 1995 
dengan luas $3.794,50 \mathrm{~m}$ persegi dan luas tanah tersedia 4 ha. Bangunan fisik terdiri atas ruang kantor, ruang Napi, Poliklinik, Masjid, dan Aula, ruang pendidikan dan perawatan. Bangunan untuk Napi terdiri atas delapan blok (Blok B sampaiblok I) dengan kapasitas huni 276 orang.

Dilihat dari penataannya (site plan), Lapas ini terbilang rapi dan indah. Bagian depan, memanjang dari utara ke selatan merupakan bangunan untuk kantor Lapas. Bangunan untuk tahanan/napi diletakkan di belakang, menghadap dari utara keselatan keruang kosong ditengah yang juga berfungsi sebagai taman dan kebun. Antara satu blok dengan blok yang lain dibatasi dengan ruang kosong tempat berangin-angin. Masjid dan Aula, yang juga dipakai sebagai sarana olahraga berada di tengah. Dari penataan bangunan yang ada sepintas terlihat tidak ada kesan Lapas. Sayang sekali, karena fasilitas persediaan air kurang, suasana amat gersang dan kering dimusim kemarau.

Pihak Lapas menilai lokasi Lapas di Jalan Raya Kariango ini kurang strategis dan penempatannya keliru.

Dalam buku pola pembinaan Narapidana/tahanan (Departemen Kehakiman RI, 1990) ketentuan tentang sarana pembinaan narapidana, sarana fisik merupakan gedung/bangunan Lapas harus memenuhi kebutuhan dan persyaratan paling minimal :

1. Letak diluar atau dipinggir kota tetapi mudah terjangkau dengan sarana transportasi dan telekomunikasi (telepon), fasilitas penerangan (listrik) dan air bersih.
2. Luas tanah/lahan Lapas Kelas I, II A, II B masing-masing minimal $60.000,40.000$, dan 30.000 meter persegi.

3. Luas gedung/bangunan Lapas Kelas I, II A, II B masing-masing $19.000,14.000$, dan 7.000 meter persegi danterletak dibagian tengah tanah/lahan.

Penetuan Kelas ini penting agar tanah/lahan selebihnya dapat dimanfaatkan untuk :

a. Menjaga keserasian bertetangga dengan masyarakat disekitarnya.

b. Menghindari agar masyarakat tidak terganggu jika ada tindakan pencegahan tehadap gangguan keamanan dan ketertiban.

c. Latihan ketrampilan pertanian dan sebagainya.

d. Keindahan (pertamanan) agar tidak mengesankan sebagai tempat yang menakutkan atau menyeramkan.

e. Sesuai dengan data kota dan keserasian lingkungan hidup.

f. Perumahan petugas dan Khusus perumahan Kalapas, Kepala Unit Satpam, Kepala Unit Pendaftaran, Kepala Unit Kesehatan dan Petugas Dapur mengambil tempat lebih dekat dengan gedung/bangunan Lapas.

4. Sedapat-dapatnya dekat dengan markas Kepolisian,Kejaksaan, dan Pengadilan. Tidak semua Persyaratan itu terpenuhi pada Lapas Maros. Paling tidak dua persyaratan penting tidak terpenuhi, yaitu telekomunikasi dan air bersih. 
terutama dimusim kemarau, yang biasanya berlangsung mulai juni sampai musim hujan tiba. Dalam keadaan demikian, air harus diangkut dengan mobil minimal 4 kali sehari, dari kampung lain, 3 km sebelah selatan Lapas. Distribusinya dijatuhkan 1 ember/orang/hari. Transportasi (oplet) beroperasi sampai ke Lapas juga terbatas sampai jam 19 malam.

\section{Keadaan Narapidana}

Tidak semua penghuni Lapas berstatus narapidana (Napi). Selain Napi terdapat juga tahanan dan orangorang titipan.

Narapidana adalah mereka yang sudah memperoleh status keputusan pengadilan dan sedang menjalani masa pidana. Napi dibagi menurut lamanya masa pidana yang harus dijalani ke dalam klasifikasi :

- Seumur Hidup :

- Golongan B I : terpidana lamanya 1 tahun keatas

- Gojongan B Ila : terpidana 1 tahun sampai 3 bulan

- Golongan B lib : terpidana 3 bulan kebawah

- Golongan III : terpidana hukuman kurungan pengganti denda.

Sedangkan tahanan adalah mereka yang sedang ditahan sementara menunggu proses pengadilan. Tahanan diklasifikasikan atas :

- Golongan A I : tahanan polisi untuk kepentingan penyidikan.

- Golongan A II: tahanan penuntut umum

- Golongan A III : tahanam Hakim

- Golongan A IV : tahanan Hakim Pengadilan Tinggi.
Penghuni Lapas Maros sampai September 1994 sebanyak 142 orang, terdiri atas 94 narapidana dan 48 tahanan. Rinciannya terlihat pada tabel dibawah ini.

Tabel: 1

Keadaan Isi LP kelas II B Maros sampai 26 September 1994

\begin{tabular}{|c|c|c|c|c|c|}
\hline & \multirow{2}{*}{ STATUS } & \multirow{2}{*}{ GOL } & \multicolumn{2}{|c|}{ KELAMIN } & \multirow{2}{*}{$\begin{array}{l}\text { JUM } \\
\text { LAH }\end{array}$} \\
\hline & & & $\mathbf{P}$ & $\mathbf{W}$ & \\
\hline \multirow[t]{2}{*}{$\mathbf{A}$} & $\begin{array}{l}\mathbf{N} \\
\mathbf{A} \\
\mathbf{P} \\
\mathbf{I}\end{array}$ & $\begin{array}{ll}\text { B } & \text { I } \\
\text { B } & \text { I l l a } \\
\text { B } & \text { l i b } \\
\text { B } & \text { I I I I }\end{array}$ & $\begin{array}{l}73 \\
21\end{array}$ & - & $\begin{array}{l}73 \\
21\end{array}$ \\
\hline & \multicolumn{2}{|c|}{ JUMLAH } & 94 & - & 94 \\
\hline \multirow[t]{2}{*}{ B } & $\begin{array}{l}\mathbf{T} \\
\mathbf{A} \\
\mathbf{H} \\
\mathbf{A} \\
\mathbf{N} \\
\mathbf{A} \\
\mathbf{N}\end{array}$ & $\begin{array}{ll}\text { A } & \text { I } \\
\text { A } & \text { I I } \\
\text { A } & \text { I I I } \\
\text { A } & \text { IV } \\
\text { A } & \text { V }\end{array}$ & $\begin{array}{r}2 \\
24 \\
21\end{array}$ & - & $\begin{array}{r}2 \\
24 \\
21\end{array}$ \\
\hline & \multicolumn{2}{|l|}{ JUMLAH } & 48 & - & 48 \\
\hline \multirow[t]{2}{*}{ C } & $\begin{array}{l}\text { TITIP- } \\
\text { AN }\end{array}$ & & " & - & - \\
\hline & \multicolumn{2}{|c|}{ JUMLAH $\mathbf{A B C}^{\bullet i}$} & 142 & & 142 \\
\hline
\end{tabular}

Sumber : Statistik LP Maros per 26 September 1994

Angka-angka tersebut, khususnya jumlah tahanan cenderung berubah-ubah setiap hari atau minggu karena banyaknya kasus tahanan yang masuk dan keluar. Dan dalam lima tahun terakhir angka-angka narapidana dan tahanan memperlihatkan trend yang konstan, dan cenderung meningkat. 
PROFIL LEMBAGA PEMASYARAKATAN MAROS

Tabel : 2

Keadaan Penghuiii Lapas Kelas II B Maros

Kurun Waktu 1989 - 1993

\begin{tabular}{|c|c|c|c|c|c|c|c|c|c|c|c|c|c|}
\hline \multirow[t]{2}{*}{ Tahun } & \multirow[t]{2}{*}{ KEL. } & \multicolumn{6}{|c|}{ TA $\mathbf{A}$ A $\mathbf{N}$ A $\mathbf{N}$} & \multicolumn{6}{|c|}{$\begin{array}{lllllllllll} & \mathbf{N} & \mathbf{A} & \mathbf{R} & \mathbf{A} & \mathbf{P} & \mathbf{I} & \mathbf{D} & \mathbf{A} & \mathbf{N} & \mathbf{A}\end{array}$} \\
\hline & & Al & A2 & A3 & A4 & A5 & JML. & SH & B I & B2a & B 2b & B3 & JML. \\
\hline 1989 & $\begin{array}{l}\mathbf{P} \\
\mathbf{W}\end{array}$ & - & $\begin{array}{r}134 \\
3 \\
137\end{array}$ & $\begin{array}{r}110 \\
3 \\
113\end{array}$ & 12 & $\begin{array}{l}3 \\
- \\
3\end{array}$ & $\begin{array}{r}259 \\
6 \\
265\end{array}$ & $\begin{array}{l}- \\
- \\
-\end{array}$ & $\begin{array}{r}46 \\
2 \\
48\end{array}$ & $\begin{array}{r}49 \\
49\end{array}$ & $\begin{array}{r}15 \\
\overline{5}\end{array}$ & $\begin{array}{l}- \\
-\end{array}$ & $\begin{array}{r}110 \\
2 \\
112\end{array}$ \\
\hline 1990 & $\begin{array}{l}\mathbf{P} \\
\mathrm{W}\end{array}$ & - & $\begin{array}{r}122 \\
1 \\
123\end{array}$ & $\begin{array}{c}123 \\
-\end{array}$ & $\begin{array}{l}8 \\
- \\
8\end{array}$ & $\begin{array}{l}2 \\
\overline{2}\end{array}$ & $\begin{array}{r}255 \\
1 \\
255\end{array}$ & $\begin{array}{l}- \\
- \\
-\end{array}$ & $\begin{array}{r}40 \\
- \\
40\end{array}$ & $\begin{array}{r}49 \\
49\end{array}$ & $\begin{array}{r}46 \\
4 \overline{6}\end{array}$ & $\begin{array}{l}- \\
- \\
-\end{array}$ & $\begin{array}{r}135 \\
135\end{array}$ \\
\hline 1991 & $\begin{array}{l}\mathrm{p} \\
\mathrm{w}\end{array}$ & $\begin{array}{r}16 \\
3 \\
19\end{array}$ & $\begin{array}{r}123 \\
8 \\
131\end{array}$ & $\begin{array}{r}105 \\
7 \\
112\end{array}$ & $\begin{array}{r}12 \\
1 \\
13\end{array}$ & $\begin{array}{l}4 \\
- \\
4\end{array}$ & $\begin{array}{r}256 \\
19 \\
275\end{array}$ & $\begin{array}{l}- \\
- \\
-\end{array}$ & $\begin{array}{r}37 \\
1 \\
38\end{array}$ & $\begin{array}{r}50 \\
2 \\
52\end{array}$ & $\begin{array}{r}32 \\
2 \\
34\end{array}$ & $\begin{array}{l}2 \\
\overline{2}\end{array}$ & $\begin{array}{r}121 \\
5 \\
126\end{array}$ \\
\hline 1992 & $\begin{array}{l}\mathrm{p} \\
\mathrm{w}\end{array}$ & $\begin{array}{r}57 \\
4 \\
61\end{array}$ & $\begin{array}{r}91 \\
5 \\
96\end{array}$ & $\begin{array}{r}89 \\
5 \\
94\end{array}$ & $\begin{array}{l}1 \\
\overline{1}\end{array}$ & $\begin{array}{l}- \\
-\end{array}$ & $\begin{array}{r}238 \\
14 \\
252\end{array}$ & $\begin{array}{l}- \\
- \\
-\end{array}$ & $\begin{array}{r}35 \\
-\end{array}$ & $\begin{array}{r}36 \\
- \\
36\end{array}$ & $\begin{array}{r}35 \\
5 \\
40\end{array}$ & $\begin{array}{l}- \\
- \\
-\end{array}$ & $\begin{array}{r}106 \\
5 \\
111\end{array}$ \\
\hline 1993 & $\begin{array}{l}\mathrm{p} \\
\mathrm{w}\end{array}$ & $\begin{array}{r}82 \\
1 \\
83\end{array}$ & $\begin{array}{r}95 \\
2 \\
97\end{array}$ & $\begin{array}{r}89 \\
3 \\
92\end{array}$ & $\begin{array}{l}7 \\
\overline{7}\end{array}$ & $\begin{array}{l}2 \\
\overline{2}\end{array}$ & $\begin{array}{r}275 \\
6 \\
281\end{array}$ & $\begin{array}{l}- \\
- \\
-\end{array}$ & $\begin{array}{r}66 \\
- \\
66\end{array}$ & $\begin{array}{r}49 \\
-\end{array}$ & $\begin{array}{r}15 \\
2 \\
17\end{array}$ & $\begin{array}{l}- \\
- \\
-\end{array}$ & $\begin{array}{r}130 \\
2 \\
132\end{array}$ \\
\hline
\end{tabular}

Sumber : Kantor Lapas Maros 1994.

Diantara Narapidana tersebut terdapat residivis berturut-turut pada tahun 1989, 15 orang; tahun 1990 , 6 orang; tahun 19918 orang; tahun 1992, 6 orang; dan tahun 1993, 4 orang.

Angka-angka perkembangan jumlah Napi dan tahanan selama lima tahun terakhir tersebut menunjukkan suatu kecenderungan yang konstan antara 250 280 untuk tahanan dan antara 110 - 135 untuk Napi. Hal itu menunjukkan masih tingginya tingkat pelanggaran hukum di kalangan masyarakat meski upaya ke arah masyarakat sadar hukum telah dilakukan.

Satu diantara banyak faktor adalah rendahnya tingkat pendidikan. Korelasi positif pelanggaran hukum dengan pendidikan ini memperlihatkan suatu kecenderungan kuat.
Tabel : 3

Latar Belakang Pendidikan Narapidana Lapas Maros 1994

\begin{tabular}{rlrlc}
\hline No. & Status & Pendidikan & F & $\%$ \\
\hline 1 & Sarjana & Lengkap & 1 & 0,9 \\
2 & Sarjana & Muda & - & - \\
3 & S L T A & 17 & 16 \\
4 & S L T P & 8 & $n^{\prime} . s$ \\
5 & SD & 22 & 20,8 \\
6 & Buta Huruf & 58 & 54,8 \\
\hline & Jumlah & 108 & 100
\end{tabular}

Sumber : Registrasi Lapas Maros sampai Agustus 1994.

Ternyata lebih separuh Narapidana adalah buta huruf dan $20 \%$ lainnya hanya Narapidana berpendidikan Sekolah Dasar. Hal ini berbanding terbalik dengan kenyataan dalam masyarakat 
dimana jumlah warga yang buta huruf semakin kecil. Kenyataan tersebut konsisten dengan latar belakang pekerjaan Napi, seperti pada tabel di bawah ini.

Tabel: 4

Keadaan Napi Lapas Maros Menurut Latar Belakang Pekerjaan

\begin{tabular}{llrc} 
No. & Pekerjaan & f & \multicolumn{1}{c}{$\%$} \\
\hline 1 & Petani & 58 & 54 \\
2 & Nelayan & 3 & 2,8 \\
3 & Buruh/tukang & 12 & 11,3 \\
& batu & & \\
4 & Sopir & 5 & 4,7 \\
5 & Dagang & 11 & 10,4 \\
6 & Tukang becak & 2 & 1,8 \\
7 & Tukang kayu & 3 & 2,8 \\
8 & Tidak menentu & 13 & 12,2 \\
\hline & Jumlah & 106 & $100 \%$
\end{tabular}

Latar belakang pekerjaan yang paling dominan adalah petani mencapai lebih dari separuh Napi (54 \%), menyusul Napi yang pekerjaannya tidak menentu (pengangguran) $(12,2 \%)$ dan buruh/tukang batu $(11,3 \%)$. Tetapi selain itu hampir semua Napi berlatar belakang pekerjaan sektor-sektor tradisional yang merupakan ciri khusus masyarakat kelas bawah dan tidak membutuhkan keahlian khusus yang diperoleh melalui pendidikan. Mereka adalah bagian dari masyarakat yang secara ekonomi dan pendidikan tergolong rendah.

Usia Napi ketika masuk di Lapas dikelompokkan tidak secara konvensional seperti pengelompokan usia pada umumnya yang memakai interval 5 atau 10 tahunan. Lapas mengelompokkan usia atas dewasa (28 tahun ke atas), dewasa muda (22 - 27 tahun), pemuda (17-21 tahun) dan anak-anak (16 tahun ke bawah). Pencatatan usia didasarkan pada saat narapidana mulai masuk Lapas.
Tabel: 5

Keadaan Napi Lapas Maros Menurut Usia ketika Masuk Lapas

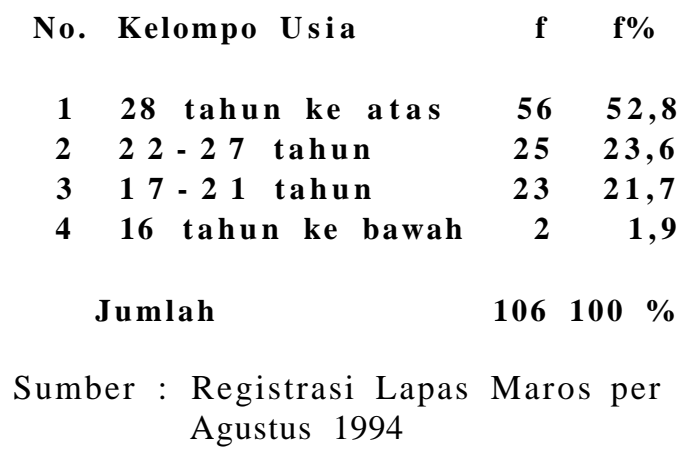

Pengelompokkan demikian selain tidak dapat melihat distribusi normal dilihat dari sudut usia, khususnya usia 28 tahun ke atas, juga menyulitkan tinjauan dari sudut psikologis dan sosiologis. Pengelompokan usia yang lebih normal dapat dilihat pada tabel berikut ini.

Tabel : 6

Keadaan Napi menurut Usia ketika masuk Lapas

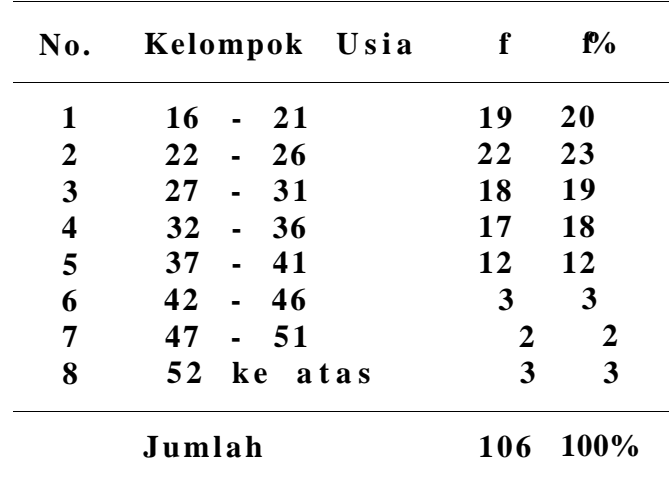

Sumber : Registrasi Lapas Maros per 14 Okt. 1994

Meski demikian, dari data yang ada terlihat proporsi Napi usia muda/remaja relatif besar yaitu mencapai 47,2 \%. Sebuah fenomena yang dilihat dari sudut Sosiologis mengarah kepada tingginya tingkat patologi Sosial bagi kaum pemuda dan remaja. 
Jenis kejahatan/pelanggaran yang dilakukan Napi sebelum masuk Lapas menunjukkan kasus-kasus tradisional seperti pembunuhan,. penganiayaan, pencurian, perampokan.

Tabel: 7

Keadaan Napi Lapas Maros Menurut Jenis Pelanggaran

\begin{tabular}{|c|c|c|c|c|c|}
\hline No. & $\begin{array}{l}\text { Jen is } \\
\text { Kesehatan }\end{array}$ & B I & B II a & Jml & $\%$ \\
\hline 1 & 2 & 3 & 4 & 5 & 6 \\
\hline 1 & Ketertiban & 1 & - & 1 & $\mathbf{0 , 0}$ \\
\hline 2 & $\begin{array}{l}\text { Mata uang/ } \\
\text { Pemalsuan }\end{array}$ & - & 2 & 2 & 1,9 \\
\hline 1 & 2 & 3 & 4 & 5 & 6 \\
\hline 3 & Kesusilaan & 2 & - & 2 & 1,9 \\
\hline 4 & Pembunuhan & 59 & - & 59 & 55,7 \\
\hline 5 & Penganiayan & 8 & 7 & 15 & 14,2 \\
\hline 6 & Pencurian & 5 & 6 & 11 & 10,2 \\
\hline 7 & Perampokan & 6 & 2 & 8 & 7,5 \\
\hline 8 & $\begin{array}{l}\text { Memeras/meng } \\
\text { ancam }\end{array}$ & 1 & - & 1 & $\mathbf{0 , 9}$ \\
\hline 9 & Penipuan & 1 & 1 & 2 & 1,9 \\
\hline 10 & La in - la in & 3 & 1 & 4 & 3,8 \\
\hline 11 & $\begin{array}{l}\text { UU } \quad \text { Drt. } \\
\text { No. } \quad 12 / 1951\end{array}$ & - & 1 & 1 & $\mathbf{0 , 9}$ \\
\hline $\mathbf{J u}$ & lah & 86 & 20 & 106 & $100 \%$ \\
\hline
\end{tabular}

Sumber : Statistik Lapas Maros per Agustus 1994

Meski ada kasus-kasus yang lain, jumlahnya jauh dibawah proporsi kasus tradisional. Kasus yang paling menonjol adalah pembunuhan, mencapai 55,7 \% (59 kasus), menyusul penganiayaan $14,2 \%$, pencurian $10 \%$, dan perampokan $7,5 \%$. Pasal-pasal KUHP yang banyak dilanggar adalah pasal 338 - 340 (pembunuhan), pasal 351 - 356 (penganiayaan), pasal 362 - 364 (pencurian), dan pasal 365 (perampokan). Motifnya selain latar belakang sosial budaya juga motif ekonomi. Keduanya saling mempengaruhi, dan juga berkaitan dengan variabael lain. Seperti rendahnya pendidikan, dan rendahnya pemahaman agama.

Nilai sosial budaya berkaitan dengan temperamen tinggi masyarakat lokal, nilai siri' dan kebiasaan membawa senjata tajam (badik). Pembunuhan dan penganiayaan ternyata memiliki sentrasentra dimana kasus tersebut banyak terjadi. Dan motif ekonomi berkaitan dengan pemenuhan salah satu kebutuhan besar, merupakan salah satu faktor. Hal ini tamapak pada fluktuasi arus tahanan pada musim-musim tertentu. Pada musim kemarau pada saat terjadi paceklik, ratio tahanan akan naik dan selanjutnya turun pada musim hujan. Boleh jadi selain karena desakan ekonomi juga karena pengaruh iklim-iklim panas lebih cepat membakar emosi daripada iklim dimusim hujan.

Tingginya proporsi kasus-kasus seperti disebutkan di atas, juga memperlihatkan Narapidana klassifikasi BI (masa pidana 1 tahun ke atas) amat tinggi, dengan pembagian $10-18$ tahun 20 orang (19 \%), 5-9 tahun 36 orang (34 $\%), 1$ - 4 tahun 30 orang $(28 \%)$ dan kurang dari 1 tahun (B Ha) 20 orang (19\%).

Persebaran narapidana menurut asal daerahnya memperlihatkan kecenderungan relatif merata, meski terjadi penonjolan pada daerah-daerah tertentu. Tabel berikut memperlihatkan keadaan Napi menurut Kecamatan/daerah asal. 
PROFIL LEMBAGA PEMASYARAKATAN MAROS

Tabel: 8

Keadaan Narapidana menurut daerah asal

\begin{tabular}{rlrr}
\hline No. & Kecamatan/Daerah & f & f\% \\
\hline 1 & Mandai & 8 & 8,3 \\
2 & Tanralili & 13 & 13,4 \\
3 & Maros Baru & 20 & 21 \\
4 & Maros Utara & 2 & 2 \\
5 & Camba/Malawa & 8 & 8,3 \\
6 & Bantimurung & 5 & 5 \\
7 & Ujungpandang & 15 & 16 \\
8 & Pangkep & 18 & 19 \\
9 & G ow a & 5 & 5 \\
10 & Bone & 2 & 2 \\
\hline & Jumlah & 96 & $100 \%$
\end{tabular}

Sumber : Registrasi Lapas per 14 Oktober 1994

\section{III, ARAH DAN STRATEGI PEMBI-} NAAN NAPI

\section{A. Sejarah Konsep Kepenjaraan}

Dalam sejarah kepenjaraan dikenal beberapa konsep dan tujuan penjara, secara berurutan, mulai dari pembalasan, penjerahan, pengasingan, rehabilitasi, sampai pada community centered/oriented.

\section{Pembalasan}

Berbuat jahat (narapidana) dinyatakan sebagai musuh masyarakat. Karena itu, pidana yang efektif ialah menyiksa mereka agar tidak berbuat jahat lagi. Pihak yang dirugikan diperbolehkan melakukan pembalasan, walaupun hak membalas itu diambil oleh Raja (King's Institution).

2. Penjerahan

Hanya sedikit dibatasi sesuai dengan kebutuhan dalam usaha pencegahan terhadap terjadinya dan atau berulangnya kejahatan.

\section{Pengasingan}

Bahwa tindakan-tindakan berupa karantina sangat diperlukan pelaksanaan pidana untuk mencegah pengulangan kejahatan oleh penjahat-penjahat yang berbahaya.

4. Rehabilitasi

Perang dunia pertama hingga menjelang perang dunia kedua timbul pemikiran yang lebih maju yang telah mendasarkan perikemanusiaan dalam dunia treatment of offenders. Manifestasinya antara lain dapat dilihat dengan dibangunnya penjara-penjara yang lebih baik dibanding dengan jaman-jaman sebelumnya, disertai pengurangan masa pidana (remisi), pemberian pelepasah bersyarat (parole), serta pengadaan fasilitas-fasilitas rehabilitasi lainnya. Namun demikian kesemuanya itu masih didasarkan pada individual centered/oriented sebagai ciri dari new penology yang berakhir kira-kira tahun 1965 .

\section{Community Contered/Oriented}

Sejak tahun 1965 timbul perubahan besar dalam dunia treatmen of offonders. New Penology ditinggalkan diganti dengan NewNew Penology, yang dalam memperlakukan narapidana lebih bersifat community oriented.

Dan Indonesia melaksanakan sistem ini relatif lebih dahulu dari negara-negara lain, dengan nama Pemasyarakatan.

Ide pemasyarakatan pertama kali 
dicetuskan oleh DR Sahardjo, SH, mantan Menteri Kehakiman, dalam pidato pengukuhan gelar Doktor Honoris Causa dalam Ilmu Hukum di Universitas Indonesia, $5 \mathrm{Juli}$ 1963, dengan judul Pohon Beringin Pengayoman. Disini ia menyebutkan : "tujuan pidana penjara adalah pemasyarakatan". Menurut Sahardjo (1986) pokok-pokok dasar dalam memperlakukan narapidana menurut kepribadian bangsa Indonesia adalah :

- bahwa tiap orang adalah manusia dan harus diperlakukan sebagai manusia, meskipun ia telah tersesat.

- bahwa tiap orang adalah anggota kemasyarakatan, tidak orang yang hidup di luar masyarakat. Karena itu narapidana harus kembali ke masyarakat sebagai warga yang berguna.

- bahwa narapidana hanya dijatuhi pidana kehilangan kemerdekaan bergerak.

\section{B. Hakekat Pemasyarakatan}

Pembinaan Napi dan tahanan didasarkan pada Keputusan Menteri Kehakiman RI, Nomor : M.02PK.04.10 tahun 1990 tentangn Pola Pembinaan Narapidana/Tahanan, ditetapkan pada 10 April 1990. Di dalamnya antara lain disebutkan bahwa, berbeda dengan sistem Kepenjaraan, sistem Pemasyarakatan menganut asas yang menempatkan tahanan, narapidana, anak negara dan klien pemasyarakatan sebagai subyek dan dipandang sebagai pribadi dan warga negara biasa, dihadapi bukan dengan latar belakang pembalasan tetapi dengan pembinaan dan bimbingan. Pembinaan dan bimbingan dilakukan melalui pembinaan mental (agama, Pencasila dsb), meliputi pemulihan harga diri sebagai pribadi maupun sebagai warga negara yang meyakini dirinya masih memiliki potensi produktif bagi pembangunan bangsa, dan oleh karena itu mereka juga dididik untuk menguasai keterampilan tertentu guna dapat hidup mandiri. Dengan bekal mental dan keterampilan yang mereka miliki, diharapkan mereka dapat berhasil mengintegrasikan dirinya di dalam masyarakat (hi. 4).

Seeara khusus pembinaan narapidana bertujuan agar selama masa pembinaan dan sesudah selesai menjalankan masa pidananya:

1. Berhasil memantapkan kembali harga diri dan kepercayaan dirinya serta bersikap optimis akan masa depannya.

2. Berhasil memperoleh pengetahuan, minimal keterampilan untuk bekal mampu hidup mandiri dan berpartisipasi dalam kegiatan pembangunan nasional.

3. Berhasil menjadi manusia yang patuh hukum yang tercermin pada sikap dan perilakunya yang tertib, disiplin, serta mampu menggalang rasa kesetiakawanan sosial.

4. Berhasil memiliki jiwa dan semangat pengabdian terhadap bangsa dan negara (hi. 10).

Guna terealisirnya tujuan tersebut, maka Pemasyarakatan dikembangkan menjadi sebuah sistem terbuka dan produktif yang berfungsi sebagai :

1. Lembaga Pendidikan yang mendidik manusia narapidana dalam rangka terciptanya kualitas manu- 
sia.

2. Lembaga Pembangunan yang mengikutsertakan manusia narapidana menjadi manusia pembangunan yang produktif (hi. 13).

Nuansa pemasyarakatan sebagai lembaga pendidikan dan lembangan pembangunan, tercermin pada SEPULUH PRINSIP PEMASYARAKATAN, yaitu :

1. Ayomi dan berikan bekal hidup agar mereka dapat menjalankan perannya sebagai warga masyarakat yang baik dan berguna.

2. Penjatuhan hukuman tidak lagi didasari oleh latar belakang pembalasan. Ini berarti tidak boleh ada penyiksaan terhadap narapidana dan anak didik pada umumnya, baik berupa tindakan, perlakuan, ucapan, cara perawatan ataupun penempatan. Satu-satunya derita yang dialami oleh narapidana dan anak didik hanya dibatasi kemerdekaannya.

3. Berikan bimbingan supaya merka bertobat. Berikan kepada mereka pengertian mengenai normanorma hidup dan kegiatan-kegiatan sosial untuk menumbuhkan rasa hidup kemasyarakatan.

4. Negara tidak berhak membuat mereka menjadi lebih buruk atau lebih jahat daripada sebelum dijatuhi pidana. Salah satu cara diantaranya agar tidak mencampur-baurkan nara-pidana dengan anak didik, yang melakukan tindak pidana berat dengan yang ringan dan sebagainya.
5. Selama kehilangan (dibatasi) kemerdekaan bergeraknya para narapidana dan anak didik tidak boleh diasingkan dari masyarakat. Perlu ada kontak dengan masyarakat yang terjelma dalam bentuk kunjungan hiburan ke Lapas dan Rutan oleh aggota masyarakat bebas dan kesempatan yang lebih banyak untuk berkumpul bersama sahabat dan keluarga.

6. Pekerjaan yang diberikan kepada narapidana dan anak dididk tidak boleh bersifat sekedar pengisi waktu. Juga tidak boleh diberikan pekerjaan untuk memenuhi keperluan jawatan atau kepentingan negara kecuali pada waktu tertentu. Pekerjaan yang terdapat di masyarakat, dan yang menunjang pembangunan, seperti meningkatkan industri kecil dan produksi pangan.

7. Pembinaan dan bimbingan yang diberikan kepada narapidana dan anak didik adalah berdasarkan Pancasila. Hal ini berarti kepada mereka harus ditanamkan semangat kekeluargaan dan toleransi disamping meningkatkan pemberian pendidikan rohani kepada mereka disertai dorongan untuk menunaikan ibadah sesuai dengan kepercayaan agama yang dianutnya.

8. Narapidana dan anak didik bagaikan orang sakit perlu diobati agar mereka sadar bahwa pelanggaran hukum yang pernah dilakukannya adalah merusak dirinya, keluarganya, dan lingkungannya.kemudian dibina/dibimbing ke jalan yang benar.

No. 12 Th. VII Juli/Desember 1995 
9. Narapidana dan anak didik hanya dijatuhi pidana berupa membatasi kemerdakaannya dalam jangka waktu tertentu.

10. Untuk pembinaan dan pembimbingan para narapidana dan anak didik, maka disediakan sarana yang diperlukan (hi. 14 - 15).

\section{Bentuk-bentuk Pembinaan}

Berdasar pada prinsip-prinsip pembinaan tersebut, metode pembinaan bersifat interaksi langsung, kekeluargaan, persuasif edukatif, berencana, terus menerus dan sistematis, melalui pendekatan individu'dan kelompok, tanpa melupakan segi-segi pemeliharaan dan pengamanan sesuai tingkat keadaan (hi. 21).

Ruang lingkup dan bentuk pembinaan mencakup pembinaan kepribadian dan pembinaan kemandirian.

1. Pembinaan kepribadian meliputi pembinaan kesadaran beragama, kesadaran berbangsa dan bernegara, kemampun kecerdasan (melalui pendidikan formal dan non-formal seperti Kejar Paket A, kursus keterampilan, ceramahceramah umum, nonton TV, membaca surat kabar, buku-buku perpustakaan dsb), termasuk juga pembinaan kesadaran hukum. Selain itu juga dilakukan pembinaan pengintegrasian diri dengan masyarakat, atau pembinaan sosial.

2. Pembinaan kemandirian meliputi keterampilan usaha mandiri, industri kecil, pengembangan bakat, dan keterampilan dibidang pertanian/perkebunan . (hi. 24).
Jika dilihat dari segi jenisnya pembinaan meliputi pembinaan mental, pembinaan sosial, dan pembinaan ketermapilan.

1. Pembinaan mental, didasarkan pada kenyataan bahwa narapidana mempuny ai problem mental, antara lain perasaan bersalah, rasa diatur, kurang bisa mengontrol emosi, rendah diri dan sebagainya. aktivitas pembinaan adalah memberi birhbingan, perhatian, memberi semangat hidup, cipta, rasa dan karsa, memberi rasa percaya diri, beribadah, mengaji, dan sebagainya.

2. Pembinaan sosial, untuk membina memperoleh dan mengembangkan pri-badi dan hidup kemasyarakatan, melalui bimbingan bermasyarakat, surat-menyurat, kunjung-mengunjungi (bezoek, cuti) dan kerja bakti.

3. Pembinaan keterampilan guna mengembangkan bakat, keahlian dan keterampilan agar menjadi modal dalam kehidupan di masyarakat nanti. Aktivitas yang dilakukan antara lain lewat training, kursuskursus pengetahuan umum, latihan kejuruan, latihan fisik, dan kesenian.

Dalam rangka pembinaan itulan, maka dalam penempatan tahanan/narapidana wajib dipertahankan penggolongan mereka berdasarkan jenis kelamin, umur, tingkat pemeriksaan, jenis perkara/jenis kejahatan resedivis, lama pidana dan kewarganegaan (hi. 28). 


\section{PRAKTEK PELAKSAAN PEM- BINAAN NAPI}

\section{A. Bentuk Pembinaan}

Dalam praktek pembinaan di Lapas Maros tampaknya tidak semua jenis pembinaan berjalan optimal. Dalam bidang pembinaan kepribadian, sosial, dan pembinaan keterampilan, yang dilaksanakan antara lain, adalah :

\section{Program Kelompok Belajar Paket A (Kejar Paket A).}

Program ini merupakan suatu proses pendidikan dan pengajaran untuk narapidana yang buta huruf dengan materi pelajaran pendidikan dasar dan pendidikan mata pencaharian yang dalam prosesnya kedua unsur tersebut dipelajari secara terpadu. Warga belajar program ini 12 orang dari 58 orang napi buta huruf. Diantara mereka ada yang masih dalam tahap pertama/dasar (A10 - A11). Tenaga pengajar direkrut dari salah seorang napi yang kebetulan sebelum masuk Lapas berstatus Guru Sekolah Lanjutan Atas. Aktivitas pengajaran berlangsung 6 kali seminggu, kecuali hari Minggu. Dibanding dengan jumlah buta huruf yang ada partisipan kelompok belajar ini amat kurang selain itu pelaksanaannya pun kurang lancar ketika penelitian dilakukan aktivitas belajar kelompok ini sedang tidak jalan. Kurangnya partisipan dan kurang lancarnya program antara lain, (1) Napi yang sudah menjalani setengah masa pidana mulai diarahkan pada aktivitas Lapas seperti tugas kebersihan, penyediaan konsumsi, membantu pekerjaan di rumah dinas, tugas mengangkat air dan pekerjaan lain yang berkaitan dengan lembaga (2) Pada umumnya napi berasal dari desa yang daya adaptasinya lama. (3) Tidak adanya tenaga pengajar yang khusus bertugas untuk itu.

\section{Penyediaan Perpustakaan}

Berkaitan dengan pengembangan wawasan dan kecerdasan napi, Lapas menyediakan perpustakaan yang buku-bukunya didrop dan diganti setiap dua kali sebulan lewat mobil Perpustakaan Keliling, dengan 30 judul buku kebanyakan buku-buku cerita sekali dropping. Buku-buku yang tersedia di Perpustakaan secara permanen hanya terbatas pada buku-buku yang berkaitan dengan kebutuhan belajar Paket A, yaitu buku-buku Aksara dan Angka, buku-buku keterampilan bercocok tanam, dan pengetahuan dasar kesehatan badan. Sementara kesenangan Napi lebih pada buku-buku cerita dan agama. Al-Qur'an yang notabene amat dibutuhkan Napi tidak terdapat stok di Perpustakaan kecuali belasan buah yang beredar di kamar-kamar Napi. Sarana informasi lain seperti surat kabar, dan televisi tidak tersedia, membuat Napi mengalami kesulitan mengikuti perkembangan yang ada di luar tembok penjara.

\section{Penyuluhan hukum, dilakukan sekali setiap semester oleh pihak Kejaksaan Negeri Maros. \\ 4. Donor darah}

Prestasi Napi Maros yang
mencolok adalah partipasinya
dalam gerakan donor darah. Tidak

No. 12 Th. VII Juli/Desember 1995 
kurang dari $60 \%$ Napi terdaftar sebagai peserta donor darah, yang dilakukan tiap 3 bulan sekali oleh PMI Ujung Pandang. Diantaranya ada yang sudah mencapai 15 kali menyumbangkan darahnya. Kebiasaan menyumbangkan darah bagi Napi bukan hanya diberikan lewat PMI tetapi juga sewaktu-waktu kalau ada keluarga Lapas yang membutuhkan.

\section{Olahraga dan seni}

Olahraga yang tersedia sarananya dan digemari banyak Napi adalah volly ball dan bulutangkis, selain catur dan domino. Dalam bidang seni Napi sendiri yang menyiapkan alatnya dari rumah seperti gitar. Kegiatan olahraga biasanya dilakukan hari Jum'at dan Ahad sesudah kerja bakti. Napi yang masih tergolong usia muda tidak jarang memanfaatkan waktu senggang dengan berkelompok memetik gitar, memukul kaleng kosong atau ember dan botol, menyerupai kelompok "band". Pertandingan olahraga seni biasanya dilakukan dalam rangkaian peringatan hari besar Nasional, terutama 17 Agustus.

Olahraga lain yang biasa dilakukan adalah senam pagi, tetapi kegiatan ini bersifat musiman, menurut kondisi persediaan air untuk mandi. Pada musim kemarau saat mana persediaan air terbatas, kegiatan senam juga berhenti.

\section{Hubungan dengan keluarga}

Frekuensi hubungan dengan keluarga melalui kesempatan bezoek dilakukan dua kali sepekan (hari Senin dan Kamis), mulai dari jam 9.00 sampai 15.00, lebih lama dari aturan yang sebenarnya (jam 9.00 sampai 14.00). Keluarga tidak dibatasi lamanya membezoek dalam interval waktu tersebut, meski menurut aturan setiap pembezoek diberi waktu 20 menit bertemu dengan Napi.

\section{Program assimilasi dan integrasi}

Program assimilasi merupakan suatu bentuk kelonggaran yang diberikan Lapas kepada Napi yang sudah menjalani minimal setengah masa pidananya dalam bentuk aktivitas di luar tembok Lapas, seperti kerja di halaman, di kebun, pemberian tugas mengambil air (khusus di musim kemarau), dan bertugas di rumah dinas.

Program integrasi dilakukan dalam bentuk pemberian kesempatan kepada Napi kembali ke masyarakat sebelum selesai masa pidananya, baik dalam bentuk cuti maupun pembebasan bersyarat. Penerima cuti selama 4 tahun terakhir 4 orang, masing-masing 2 orang pada tahun 1992 dan 2 orang tahun 1994. Pembebasan bersyarat diperoleh 12 orang tahun 1991, 10 orang pada tahun 1992, 4 orang pada tahun 1993, dan 11 orang pada tahun 1994. Syarat minimal pembebasan bersyarat secara administratif antara lain (1) sudah menjalani 2/3 masa pidana, (2) ada jaminan dari keluarga disertai pernyataan tertulis, (3) tidak mempunyai perkara Iain, (4) mempunyai laporan hasil penelitian dari Bispa (Balai Bimbingan Kemasyarakatan dan Pengetahuan Anak). 
Selain itu terdapat syarat substantif, yakni berkelakuan baik, paling tidak minimal dalam tahun terakhir sebelum diusulkan, yang bersangkutan tidak melakukan pelanggaran disiplin.

\section{Remisi}

Setiap tanggal 17 Agustus Pemerintah memberikan remisi kepada Napi yang berkelakuan baik, bukan residivis, dan sudah menjalani pidana minimal 6 bulan. Ukuran kelakuan baik minimal tidak mengambil barang sesama Napi, tidak berjudi, minum minuman keras dan melawan petugas. Besarnya remisi yang dapat diperoleh Napi bertahap menurut lamanya menjalani masa pidana. Tahun pertama, 1-2 bulan, tahun kedua 3 bulan, tahun ketiga 4 bulan, tahun keempat dan kelima dan tahun keenam dan seterusnya 6 bulan. Remisi tambahan diberikan kepada Napi yang selain memenuhi syarat di atas juga telah ikut donor darah dengan ketentuan 5 sampai 15 kali donor mendapat tambahan sebulan remisi; ikut donor selama 20 sampai 30 kali mendapat tambahan remisi 2 bulan.

\section{Keterampilan}

Pembinaan keterampilan di Lapas Maros adalah satu diantara banyak hal yang amat ketinggalan. Satu-satunya keterampilan yang jalan adalah keterampilan membuat asbak, bingkai foto, guci dan berbagai bentuk hiasan dengan menggunakan bahan serbuk gergaji dan nasi (sisa, sebelum basi). Dalam satu bulan seorang dapat menyelesaikan 4 guci dengan harga jual 17.500 - 25.000 rupiah. Pembelinya pengunjung dari keluarga Napi sendiri. Napi yang terlibat dalam keterampilan hanya beberapa orang sehingga produksinya pun terbatas. Tidak berkembangnya keterampilan ini karena tidak dimanage dengan baik dan sungguh-sungguh dan faktor pendanaan. Selain keterampilan yang mereka sebut "peco" itu, pernah juga ada keterampilan membuat tempat tissu dari kayu, tetapi kemudian macet. Juga usaha membuat kasur, karena ada pesanan dari luar dan kebetulan ada Napi yang terampil membuat kasur. Kendala utama tidak berkembangnya pembinaan keterampilan adalah (1) hambatan pemasaran, (2) tidak adanya pasokan alat-alat keterampilan dari atas, atau dari instansi/p//iak terkait, (3) tidak ada pengusaha yang tertarik memberikan investasi, (4) belum ada kerjasama dengan pihak BLK, (5) kurangnya promosi ke luar, akan potensi produktif Napi.

\section{B. Pembinaan Keagamaan}

\section{Bentuk Pembinaan}

Sebagaimana halnya pembinaan dalam bidang lainnya, pembinaan keagamaan belum diarahkan pada suatu sistem pembinaan memadai, langgeng dan terprogram. Tahuntahun sebelumnya, ceramah/pengajian terprogram pernah dilaksanakan dua kali sebulan, ditangani langsung oleh Kepala Kantor Departemen Agama Maros, Drs. H. Syukri Limpo. Setelah pergantian Kepala Kantor Depag 
Maros, program itu juga berhenti. Demikian juga halnya pengajian dasar, selama ini dimasukkan sebagai salah satu mata pelajaran Kelompok Belajar Program Paket A, bersama pelajaran shalat. Ketika aktivitas kejar Paket A tidak jalan, praktis pengajian itu juga ikut mandeg. Pengajian dasar juga pernah diajarkan oleh salah seorang Napi kepada sesama temannya yang berminat.

Bentuk pembinaan keagamaan yang langgeng adalah aktivitas yang berkaitan dengan pelaksanaan ibadah dan syiar Islam, yaitu :

\section{a. Khutbah Jum'at.}

Khutbah Jum'at dapat berjalan lancar, karena selain merupakan tuntutan wajib bagi terlaksananya shalat Jum'at juga karena yang menjadi khatib adajah pegawai Lapas sendiri. Mereka terdiri atas empat orang, ditugaskan oleh Kantor secara terjadwal, masing-masing adalah :

- Drs. Jamaluddin B (Kasubsi Kegiatan Kerja):

- Sirajuddin (staf Subsi Kegiatan Kerja)

- Ahmad (staf Kesatuan Pengamanan Lapas)

- Muhammad Palappang (Kepala Urusan Umum).

Diantara keempat petugas tersebut hanya satu yang berlatar belakang pendidikan agama (PGA). Selainnya lebih karena tugas dan dengan modal belajar sendiri. Buku rujukan yang dipergunakan tidak banyak variasi. Umumnya, buku tuntunan khutbah, buku Fiqhi Islam (Sulaiman Rasyid) dan buku- buku Al-Gazaly untuk akhlak dan tasawuf.

Materi Khutbah berkisar pada hal-hal yang pokok dalam ajaran agama, dan kaitan dengan kehidupan sehari-hari, kaitan dengan bulan-bulan Qamariah tertentu. Meski yang melaksanakan tugas khutbah orang Lapas sendiri, mereka tidak merasa perlu mengatur materi khutbah menurut kepentingan pengajaran agama secara bertahap dan sistematis. Sebaliknya, karena alasan tidak ada rotan akar pun jadi, tema-tema materi khutbah diangkat sesuai kapasitas, dan "selera" khatib, serta disampaikan tanpa naskah. Dengan mempergunakan bahasa Indonesia sebagai pengantar, pernyataan-pernyataan yang dianggap penting didukung dengan bahasa daerah (Makassar, Bugis). 
""^T

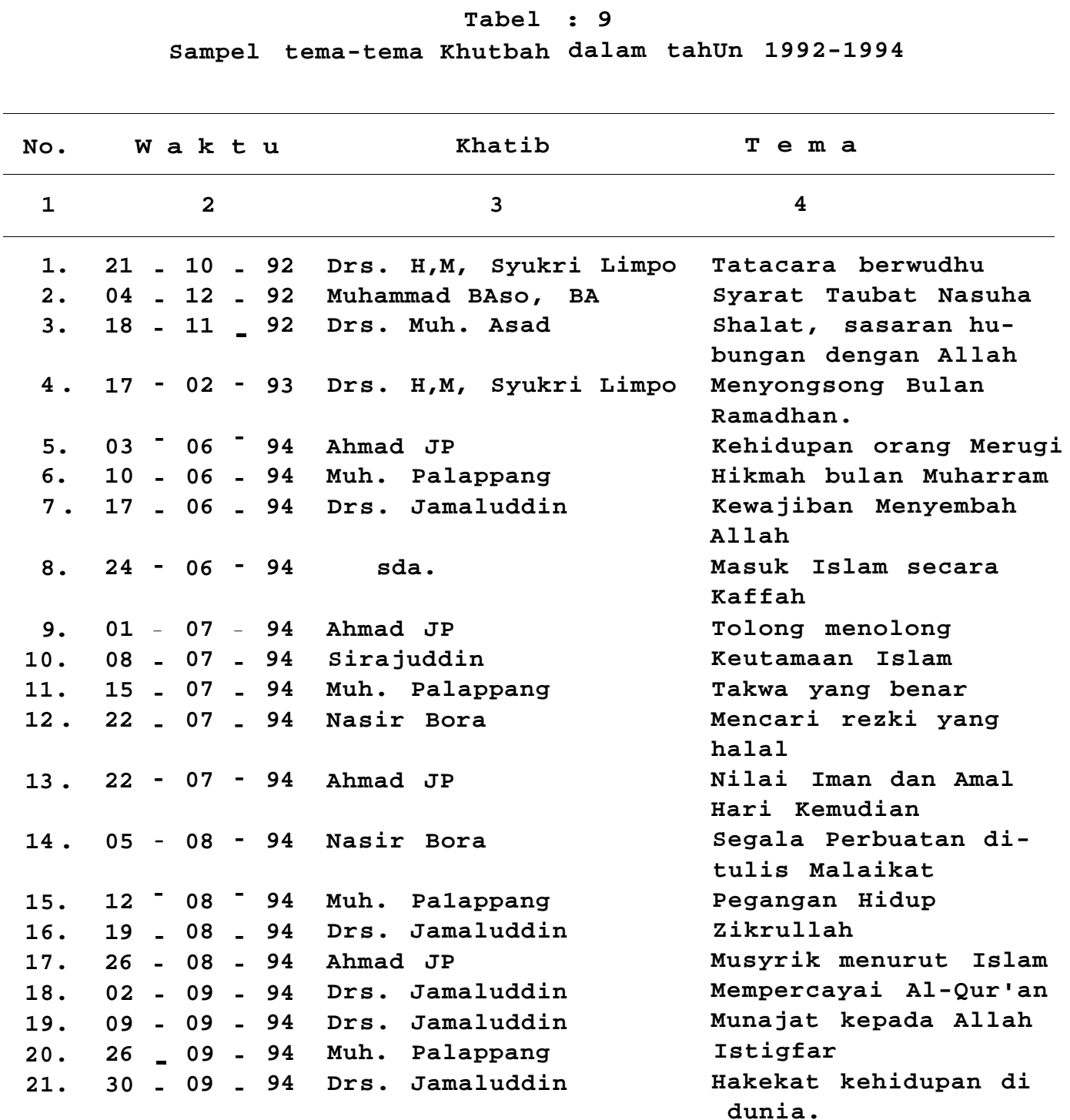

Betapa pun, kemampuan mereka untuk menangani khutbah sendiri merupakan suatu hal yang patut diacungi jempol. Namun, karena yang baca khutbah terbatas pada petugas itu saja, yang notabene hubungannya sehari-hari dengan narapidana diikat oleh hubungan antara "penjaga" dan yang "dijaga", timbul kesan adanya jarak psikologis dan kecenderungan jenuh. Sementara untuk mendatangkan khatib dari luar, selain karena faktor dana juga karena faktor kejauhan, baik dari kota Maros, apalagi dari Ujung Pandang dari mana potensi khatib dapat diharapkan.

No. 12 Th. Vn Juli/Desember 1995 


\section{b. Amaliah Ramadhan}

Bobot pembinaan yang secara inklusif merupakan bagian tak terpisahkan dari kewajiban orang Muslim adalah puasa dalam bulan Ramadhan. Baik ikhlas maupun tidak, keharusan berpuasa memang harus diikuti karena adanya perubahan total pelayanan makan, yang hanya berlaku untuk makan sahur dan buka puasa. Dalam bulan Ramadhan inilah suasana keagamaan lebih jelas dari bulan-bulan biasa. Sebagaimana kaum Muslimin pada umumnya, mereka juga menyemarakkan bulan Ramadhan dengan tarwih bersama di mesjid Lapas, mendengar ceramah setiap malam, dan tadarus AlQur'an. Selain dibawakan keempat muballig intern Lapas, seperti telah disebutkan, juga dijadwalkan empat kali ceramah dibawakan orang dari luar. Sedangkan tadarrus kecuali dilakukan sendiri-sendiri oleh Napi yang mampu pada saat tertentu, juga dilakukan berkelompok dalam mesjid sesudah shalat tarwih sampai sekitar jam 23.00.

\section{c. Peringatan Hari-hari Besar Islam}

Peringatan hari besar Islam seperti Iedul Fitri, Iedul Adha, halal bi halal, Maulid, dan Isra Mi'raj dirayakan secara rutin dalam Lapas. Pada kesempatan ini bukan saja narapidana yang diharuskan ikut, tetapi juga keluarga mereka diundang mengikuti perayaan. Kecuali bertujuan memetik hikmah dari per- ingatan tersebut, juga mengupayakan silaturrahmi dan assimilasi akan lebih tampak. Kesempatan seperti itu dimanfaatkan untuk mengundang penceramah/khatib dari luar Lapas. 
Jenis Pembinaan $\mathrm{Napi}$

1. Kesadaran Beragama

a.Pelajaran membaca AlQur'an

b. Pengajian rutin

c. Amaliah Ramadhan

d. Shalat Jum'at

e. Khutbah Jum'at

f. Hari Besar Is lam

g. Kurban

2. Kesadaran Berbangsa dan bernegara.

- Penataran P4

3. Ke cerdas an

a.Pendidikan formal $\quad \mathbf{X}$

b. Kursus

c. Diklat keterampilan

d. Ceramah umum

e. Memperoleh informasi

dari luar melalui:

- koran/majal a h

- t e levis i

$-\mathrm{r}$ a dio

f. Kejar Paket A

g. Kejar Usaha

4. Kes adaran Hukum

a.Penyuluhan Hukum

b. K a d a r k u m

c.Temu Sadar Hukum

5. Pembinaan $\mathrm{S}$ osia 1

a. bi m bing a n

b. surat-meny u r a t

c. be zoe k

d. c u t i

e.pembebasan bersyarat

f. $\mathrm{rem}$ is i

g. kerja bakti

6. Ke te r a m pila

a.Diklat kejujuran

b. Usaha mandiri

c. Usaha industri kecil

d. Keterampilan se suai

bakat masing-masing

e. Latihan fisik/seni

- se nan pagi

- olah raga

- a t l e t i k

- seni musuk
Skala pelaksana n

$\mathbf{X}$

$\mathbf{X}$

$\mathbf{X}$

$\mathbf{X}$

$\mathbf{X}$

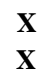

$\mathbf{X}$

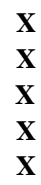

$\mathbf{X}$

$\mathbf{X}$

$\mathbf{X}$

$\mathbf{X}$

$\mathbf{X}$ 
PROFIL LEMBAGA PEMASYARAKATAN MAROS

Keterangan :

$0=$ tidak ada, tidak jalan

$1=$ pernah ada

$2=$ ada tetapi tidak lancar

$3=$ kurang lancar

$4=$ lancar

\section{Masalah Pembinaan}

Meskipun telah banyak yang dilakukan Lembaga Pemasyarakatan Kelas I Ujungpandang dalam pembinaan narapidana, namun masih banyak program pembinaan yang tidak diadakan atau pelaksanaannya belum optimal sebagai strategi mencapai tujuan pembinaan yaitu terwujudnya anak/peserta binaan yang memiliki kemampuan keterampilan dan kemandirian. Hal itu disebabkan oleh banyak faktor, antara lain :

1. Masalah Pendahaan

Faktor dana merupakan faktor hambatan utama bagi dilakukannya pembinaan secara baik dan langgeng. Dana rutin sangat terbatas sehingga tidak dapat diharapkan untuk membiayai pelaksanaan pembinaan, terutama untuk pembinaan keagamaan. Dana rutin sangat terbatas, sementara dana proyek belum memiliki pos untuk allokasi untuk pembinaan keagamaan. Idealnya, untuk merehabilitasi Napi sebagai manusia bermasalah, perlu ditunjang oleh kesungguhan yang wujudnya antara lain pengadaan dana proyek pembinaan. Penghasilan yang diperoleh Naripadana sebagai imbalan dari pekerjaan keterampilan rotan, sebenarnya dapat dimanfaatkan untuk biaya ekspansi dan memperbanyak ragam dan jenis keterampilan selain keterampilan industri rotan.
Untuk sejumlah uang yang dihasilkan Napi lebih efektif jika dikelola oleh Lapas sendiri guna keperluan tersebut, daripada dimasukkan kg Kas Negara.

2. Masalah Ketenagaan

Ketenegaan dalam pembinaan sebagian besar amat tergantung pada Napi. Tenaga terampil berbagai bidang yang khusus direkrut sebagai pegawai untuk memenuhi kebutuhan pembinaan baik keterampilan umum maupun pembinaan keagamaan dan jenis pembinaan lainnya, amat terbatas jumlahnya. Dalam pembinaan keagamaan, misalnya, meski sudah diikat kerja sama dengan pihak IAIN Alauddin, efektivitasnya belum dapat disebut berhasil, karena berbagai masalah interen IAIN sendiri, Dari interen Lapas sendiri, secara praktis bidang ini tidak didukung oleh staf yang secara khusus bertugas untuk memberi bimbingan dan pembinaan keagamaan. Karena itu, pemberian bimbingan dan pembinaan keagamaan. Karena itu, pemberian bimbingan lebih bersifat suka rela dan dilaksanakan oleh volunteer dari kalangan pegawai, yang sebenarnya bertugas di bidang lain, dan dari kalangan napi sendiri, jika secara kebetulan ada yang mampu. Kurangnya tenga juga masih dipengaruhi lagi oleh program pembinaan yang kurang didukung oleh penyiapan perangkat lunak, seperti sillaby dan kurikulum.

3. Keterlibatan pihak lain

Keterlibatan pihak lain terbatas untuk dapat mengembangkan ber- 
PROFIL LEMBAGA PEMASYARAKATAN MAROS

bagai jenis pembinaan, kecuali Instansi atau perusahaan tertentu seperti PT GIMEX yang dikondisikan dari Pusat. Berbagai Departemen misalnya Departemen Tenaga Kerja, Koperasi, belum melakukan intervensi secara optimal. Pembinaan dari Departemen Agama belum konsisten sebagai suatu upaya terprogram dan continue. Lembaga-lembaga dakwah juga belum ada yang melibatkan diri dalam pembinaan secara terpola. Padahal pembinaan amat dibutuhkan berdasarkan kondisi obyektif narapidana yang secara psikologis dan sosiologis senantiasa siap untuk menerima bimbingan demi rehabilitasi mental demi kehidupan yang lebih baik. Latar belakang budaya narapidana, yang masih menjunjung tinggi nilai-nilai agama dan melihat orang yang menjalankan amalan agama, sebagai orang baik. Potensi luaran juga cukup besar untuk dilibatkan dalam kerjasama pembinaan, baik Depag sendiri maupun lembaga dakwah dan perguruan tinggi Islam. Dilihat dari segi fasilitas fisik, keberadaan mesjid di tengahtengah Lapas sangat mendukung program pembinaan di bidang keagamaan..

\section{Masalah Komitmen}

Pembinaan yang betul-betul diharapkan dapat membawa hasil yang baik sebagaimana secara ideal ditetapkan dalam Pola Pembinaan Narapidana/Tahanan memerlukan komitmen tinggi dari semua pihak untuk melaksanakannya.Jika hanya political/good will saja tanpa didukung komitmen tinggi, khusus- nya dari pihak instansi bersangkutan sebagai pelaksana, maka nuansa pembinaan Napi akan menjadi masalah berkepanjangan. Komitmen kuat, antara lain dapat dilakukan dengan melakukan optimalisasi penyediaan perangkat pendukung dan pengkodisian infrastruktur yang memadai, baik di bidang ketenagaan, pendanaan, kemitraan dan implementasi.

\section{Persepsi Napi Terhadap Pembinaan}

Dari angket yang diisi oleh 16 warga Lapas, terdiri atas 12 Napi dan 4 pegawai, serta hasil wawancara mendalam terhadap Kepala Seksi Bimbingan Napi/Anak Didik dan Kegiatan Kerja dan 7 orang Napi diketahui bahwa pembinaan keagamaan di Lapas dirasakan masih perlu ditingkatkan. Terutama adalah keinginan agar ada bimbingan agama secara khusus di luar cara-cara konvensional yang selama ini mereka peroleh. Mereka sangat menghargai pembinaan yang pernah berjalan setahun sebelumnya dimana ada pengajian khusus yang diberikan aparat Departemen Agama. Dan hal itu dirasakan besar manfaatnya, terutama dalam meningkatkan pengetahuan dan pengamalan ajaran agama.

Hal lain yang dinilai perlu diadakan adalah buku-buku agama. Banyak napi ingin belajar agama melalui buku-buku tetapi bukunya tdak ada. Yang ada, tetapi sangat terbatas, hanya Al-Qur'an tanpa terjemahan. Jenis buku yang banyak diharapkan adalah penuntun ibadah.

Berada di Lapas, menurut Napi, membawa hikmah, antara lain ingin 
dekat dengan Tuhan. Karena itu, kalau di luar pelaksanaan ibadah shalat dan kebiasaan mengaji misalnya, tidak rutin, di dalam Lapas ini semakin mantap. Banyaknya waktu luang dan isolasi di bali tembok Lapas, antara lain, dianggap sebagai faktor penunjang kebutuhan akan belajar dan mengamalkan agama lebih dari apa yang merekalakukan sebelum berada di Lapas.

Pembinaan napi, khususnya dalam pembinaan keagamaan, paling tidak didasarkan pada dua asumsi pokok. Pertama, bahwa napi adalah orang bermasalah, baik dilihat dari sudut nilai budaya, norma sosial dan norma agama. Kedua bahwa berada dalam Lapas adalah peluang untuk melakukan pemulihan dan pembinaan dilihat dari berbagai segi.

Berdasarkan asumsi di atas, seharusnya pembinaan napi, termasuk pembinaan keagamaan merupakan suatu langkah krusial yang hendaknya dilakukan sungguh-sungguh, lebih dari apa yang biasanya dilakukan terhadap orang yang tidak bermasalah.

Pembinaan itu harus dilihat dari berbagai sudut, metode, materi dan terutama strategi pembinaan dan good will dari pengambil kebijakan, dalam hal ini Departemen Kehakiman dan Departemen Agama.

Pembinaan keterampilan juga dirasakan Napi sebagai sesuatu yang mendesak untuk diadakan agamr mereka memiliki bekal untuk memasuki hidup baru setelah keluar dari Lapas. Selain itu, mereka menilai kegiatan keterampilan dalam Lapas juga dirasakan besar manfaatnya untuk mengisi masa-masa panjang dalam Lapas dan mengusir kejenuhan.

\section{BAB V \\ PENUTUP}

\section{A. Simpulan}

Dari uraian terdahulu dapat disimpulkan beberapa hal sebagai berikut :

1. Bahwa citra penjara yang sebelumnya berkesan sebagai tempat hukuman, penjerahan terhadap narapidana kemudian berubah menjadi Lembaga Pemasyarakatan yang lebih ditekankan pada makna pembinaan membawa perspektif baru bagi perkembangan lembaga tersebut.

2. Pembinaan bagi Napi, dengan demikian, telah memiliki suatu pola baru yang intinya bagaimana mempersiapkan mereka agar mampu kembali ke masyarakat dengan membekali berbagai pengetahuan, sikap, prilaku dan keterampilan yang dibutuhkan dalam memasuki hidup baru di masyarakat nanti. Secara garis besar ada tiga jenis pembinaan yang seharusnya diberikan kepada narapidana : (a) pembinaan mental spritual dan wawasan, (b) pembinaan sosial, dan (c) pembinaan keterampilan. Hal ini berlaku untuk semua Lapas.

3. Bagi Lapas tertentu, sebagaimana halnya di Lapas Kelas II B Maros, pola pembinaan tersebut pada poin dua di atas, sebagiannya sudah terlaksana tetapi sebagiannya lagi 
belum dapat terwujud. Bidang yang terlaksana umumnya bidang pembinaan spritual dan pembinaan sosial atau sosialisasi. Meski demikian pelaksanaan di bidang tersebut belum merupakan suatu pembinaan yang terarah, terprogram dengan sasaran yang jelas, sebab seperti pembinaan keagamaan masih berkutat pada pelaksanaan ibadah rutin, pengajian dasar, khutbah, perayaan hari besar Islam. Padahal sebagai orang bermasalah, narapidana sesungguhnya membutuhkan pendekatan khusus dan intensif di bidang mental spritual. Demikian juga halnya pembinaan keterampilan belumlah seperti apa yang digariskan dalam Pola Pembinaan Baku. Keterampilan yang dilakukan amat terbatas pada keterampilan memanfaatkan limbah makanan dalam Lapas dan kerajinan membuat bingkat foto dan sebagainya yang jalannya amat tergantung pada inisiatif Napi tertentu, karena tidak adanya sumber dana dari Lapas atau pihak lain.

4. Di antara banyak faktor yang menjadi kendala kurang fungsionalnya pembinaan Napi sesuai Pola Pembinaan yang baku adalah faktor terbatasnya dana. Dana Lapas terbatas pada dana rutin, yang tidak mencakup allokasinya kepada pembinaan ketiga bidang tersebut. Selain itu, terbatasnya sumberdaya manusia yang dimiliki Lapas yang khusus menangani pembinaan tersebut, dibanding dengan kebutuhan narapidana akan hal itu merupakan kendala lain. Rekruitmen ketenagaan yang memiliki latar belakang pendidikan/keterampilan khusus sesuai dengan kebutuhan pembinaan juga masih belum terlaksana. Kendala-kendala Internal tersebdt berlangsung bersamaan dengan belum terlibatnya instansi/pihak lain secara kelembagaan. Selain karena faktor-faktor teknis, antara lain jauhnya lokasi Lapas di luar kota Maros, persediaan air bersih yang masih bertumpu pada sumur penduduk, juga karena kurangnya komitmen pihak-pihak di luar Lapas bagi kepentingan pembinaan Napi.

5. Meski sudah berubah menjadi Lembaga Kemasyarakatan, kesan masyarakat terhadap lembaga tersebut belum banyak berubah bahwa lembaga pemasyarakatan itu adalah penjara sebagimana pernah dianut sebelumnya.

\section{B. Saran}

Guna mengatasi masalah-masalah tersebut direkomendasikan hal-hal sebagai berikut :

1. Perlu rekruitmen sumberdaya manusia yang memiliki latar belakang pendidikan/keterampilan khusus sesuai dengan kebutuhan pembinaan baik pembinaan mental spritual (dari mereka yang berlatar belakang pendidikan agama), pembinaan keterampilan (dari mereka yang berlatar belakang pendidikan kejuruan/teknik).

2. Perlu adanya dana khusus (proyek atau rutin) yang allokasinya ditujukan bagi program-program pembinaan Napi. Selain dari Pemerintah dana juga dapat diusahakan dari sumber-sumber lain, misalnya dengan memanfaatkan dana BUMN 
dekat dengan Tuhan. Karena itu, kalau di luar pelaksanaan ibadah shalat dan kebiasaan mengaji misalnya, tidak rutin, di dalam Lapas ini semakin mantap. Banyaknya waktu luang dan isolasi di bali tembok Lapas, antara lain, dianggap sebagai faktor penunjang kebutuhan akan belajar dan mengamalkan agama lebih dari apa yang merekalakukan sebelum berada di Lapas.

Pembinaan napi, khususnya dalam pembinaan keagamaan, paling tidak didasarkan pada dua asumsi pokok. Pertama, bahwa napi adalah orang bermasalah, baik dilihat dari sudut nilai budaya, norma sosial dan norma agama. Kedua bahwa berada dalam Lapas adalah peluang untuk melakukan pemulihan dan pembinaan dilihat dari berbagai segi.

Berdasarkan asumsi di atas, seharusnya pembinaan napi, termasuk pembinaan keagamaan merupakan suatu langkah krusial yang hendaknya dilakukan sungguh-sungguh, lebih dari apa yang biasanya dilakukan terhadap orang yang tidak bermasalah.

Pembinaan itu harus dilihat dari berbagai sudut, metode, materi dan terutama strategi pembinaan dan good will dari pengambil kebijakan, dalam hal ini Departemen Kehakiman dan Departemen Agama.

Pembinaan keterampilan juga dirasakan Napi sebagai sesuatu yang mendesak untuk diadakan agamr mereka memiliki bekal untuk memasuki hidup baru setelah keluar dari Lapas. Selain itu, mereka menilai kegiatan keterampilan dalam Lapas juga dirasakan besar manfaatnya untuk mengisi masa-masa panjang dalam Lapas dan mengusir kejenuhan.

\section{BAB V PENUTUP}

\section{A. Simpulan}

Dari uraian terdahulu dapat disimpulkan beberapa hal sebagai berikut :

1. Bahwa citra penjara yang sebelumriya berkesan sebagai tempat hukuman, penjerahan terhadap narapidana kemudian berubah menjadi Lembaga Pemasyarakatan yang lebih ditekankan pada makna pembinaan membawa perspektif baru bagi perkembangan lembaga tersebut.

2. Pembinaan bagi Napi, dengan demikian, telah memiliki suatu pola baru yang intinya bagaimana mempersiapkan mereka agar mampu kembali ke masyarakat dengan membekali berbagai pengetahuan, sikap, prilaku dan keterampilan yang dibutuhkan dalam memasuki hidup baru di masyarakat nanti. Secara garis besar ada tiga jenis pembinaan yang seharusnya diberikan kepada narapidana : (a) pembinaan mental spritual dan wawasan, (b) pembinaan sosial, dan (c) pembinaan keterampilan. Hal ini berlaku untuk semua Lapas.

3. Bagi Lapas tertentu, sebagaimana halnya di Lapas Kelas II B Maros, pola pembinaan tersebut pada poin dua di atas, sebagiannya sudah terlaksana tetapi sebagiannya lagi 
PROFIL LEMBAGA PEMASYARAKATAN MAROS

belum dapat terwujud. Bidang yang terlaksana umumnya bidang pembinaan spritual dan pembinaan sosial atau sosialisasi. Meski demikian pelaksanaan di bidang tersebut belum merupakan suatu pembinaan yang terarah, terprogram dengan sasaran yang jelas, sebab seperti pembinaan keagamaan masih berkutat pada pelaksanaan ibadah rutin, pengajian dasar, khutbah, perayaan hari besar Islam. Padahal sebagai orang bermasalah, narapidana sesungguhnya membutuhkan pendekatan khusus dan intensif di bidang mental spritual. Demikian juga halnya pembinaan keterampilan belumlah seperti apa yang digariskan dalam Pola Pembinaan Baku. Keterampilan yang dilakukan amat terbatas pada keterampilan memanfaatkan limbah makanan dalam Lapas dan kerajinan membuat bingkat foto dan sebagainya yang jalannya amat tergantung pada inisiatif Napi tertentu, karena tidak adanya sumber dana dari Lapas atau pihak lain.

4. Di antara banyak faktor yang menjadi kendala kurang fungsionalnya pembinaan Napi sesuai Pola Pembinaan yang baku adalah faktor terbatasnya dana. Dana Lapas terbatas pada dana rutin, yang tidak mencakup allokasinya kepada pembinaan ketiga bidang tersebut. Selain itu, terbatasnya sumberdaya manusia yang dimiliki Lapas yang khusus menangani pembinaan tersebut, dibanding dengan kebutuhan narapidana akan hal itu merupakan kendala lain. Rekruitmen ketenagaan yang memiliki latar belakang pendidikan/keterampilan khusus sesuai dengan kebutuhan pembinaan juga masih belum terlaksana. Kendala-kendala Internal tersebtft berlangsung bersamaan dengan belum terlibatnya instansi/pihak lain secara kelembagaan. Selain karena faktor-faktor teknis, antara lain jauhnya lokasi Lapas di luar kota Maros, persediaan air bersih yang masih bertumpu pada sumur penduduk, juga karena kurangnya komitmen pihak-pihak di luar Lapas bagi kepentingan pembinaan Napi.

5. Meski sudah berubah menjadi Lembaga Kemasyarakatan, kesan masyarakat terhadap lembaga tersebut belum banyak berubah bahwa lembaga pemasyarakatan itu adalah penjara sebagimana pernah dianut sebelumnya.

\section{B. Saran}

Guna mengatasi masalah-masalah tersebut direkomendasikan hal-hal sebagai berikut :

1. Perlu rekruitmen sumberdaya manusia yang memiliki latar belakang pendidikan/keterampilan khusus sesuai dengan kebutuhan pembinaan baik pembinaan mental spritual (dari mereka yang berlatar belakang pendidikan agama), pembinaan keterampilan (dari mereka yang berlatar belakang pendidikan kejuruan/teknik).

2. Perlu adanya dana khusus (proyek atau rutin) yang allokasinya ditujukan bagi program-program pembinaan Napi. Selain dari Pemerintah dana juga dapat diusahakan dari sumber-sumber lain, misalnya dengan memanfaatkan dana BUMN

No. 12 Th. VII Juli/Desember 1995 
PROFIL LEMBAGA PEMASYARAKATAN MAROS

(SEBUAH KASUS EVALUATIF TERHADAP PELAKSANAAN PEMBINAAN NARAPIDANA)

yang disiapkan bagi pengembangan usaha berskala kecil.

3. Pihak Lapas perlu mengupayakan hubungan dengan instansi lain, memberikan informasi, dan bahkan "menjual" potensi narapidana kepada berbagai pihak agar mereka tertarik dan memiliki komitmen untuk bersama-sama melakukan pembinaan.

4. Citra Lembaga Pemasyarakatan sebagai suatu lembaga yang seram, tertutup urituk diketahui secara luas, dapat dikurangi dengan mengadakan penyebaran informasi secara luas melalui berbagai saluran, baik formal maupun informal.

\section{DAFTAR PUSTAKA}

\section{Badan Pembinaan Hukum Nasional Departemen Kehakiman, Pem- binaan Sistem Kemasyarakatan, tidak diterbitkan, proyek tahun 1986/1987.}

Departemen Kehakiman Republik Indonesia, Pola Pembinaan Narapidana/Tahanan, Cetakan I, tahun 1990.

Hamzah, Andi DR. SH, Pengantar Hukum Acara Pidana Indonesia, Ghalia Indonesia, Jakarta, 1987.

Lamintang, Drs.,P.A.F.,SH, dan Samosir, C. Djisman.SH, Hukum Pidana Indonesia, Sinar Baru, Bandung, 1985.

Moeljatno, Prof.SH, KUHP (Kitab Undang-Undang Hukum Pidana), Bina Aksara, Jakarta, 1985.

\author{
Soesilo, R, Hukum Acara Pidana \\ (Prosedur Penyelesaian Perkara \\ Pidana menurut KUHAP bagi \\ Penegak Hukum), Politeia, Bogor, \\ 1982. \\ Kitab Undang-Undang Hukum \\ Pidana (Serta Komentar-Komen- \\ tarnya Lengkap Pasal demi \\ Pasat), Politeia, Bogor, 1988.
}

